\title{
Characteristics of Mediastinal Tumors in Dr. Hasan Sadikin General Hospital, Periods of 2011-2016
}

\author{
Octavianus Giovani, Hasrayati Agustina ${ }^{* *}$, Teguh M Djajakusumah ${ }^{\text {***** }}$ \\ *Faculty of Medicine Padjadjaran University \\ ** Department of Anatomical Pathology \\ Faculty of Medicine Padjadjaran University - Dr. Hasan Sadikin General Hospital \\ *** Department of Surgery, Vascular Surgery Division \\ Faculty of Medicine, Padjadjaran University - Dr. Hasan Sadikin General Hospital \\ Jl. Prof. Eyckman No. 38, Bandung, 40161 \\ Email :octavianusgio@gmail.com
}

\begin{abstract}
Mediastinal tumors are considered to be mediastinal disease with various clinical and histopathologic presentations. In Indonesia, literatures concerning mediastinal tumors are still few. This study aims to obtain the characteristic of mediastinal tumors in Dr.Hasan Sadikin Hospital. A cross-sectional retrospective study was conducted using medical records from 2011 to 2016. All medical records with clinical diagnosis of mediastinal tumors are included, and cases with metastatic tumors from distant sites to the mediastinum, and/or incorrect histopathologic findings are excluded. We obtain data of age, gender, clinical symptoms, histopathologic finding, and staging, with total samples collected of 72. We find out that patients with mediastinal tumors are mainly over 40 years old $(62.5 \%)$, especially in the 6th decade of life (23.6\%), and were mostly of males (73.6\%). Patients mainly had chief complaints of dyspnea (38.7\%), followed by cough and typical myasthenia gravis symptoms. The most common type of mediastinal tumor is epithelial cell tumor (68.4\%), and the most common stage is Masaoka-Koga stage III (37.5\%). This study concludes that mediastinal tumor mainly occurs in males aged 40 years old and above, with epithelial cell tumor as the most common histopathologic findings.
\end{abstract}

Keywords : characteristics; mediastinal tumor; mediastinum 


\title{
Karakteristik Tumor Mediastinum di RSUP Dr. Hasan Sadikin Bandung Periode 2011-2016
}

\author{
Octavianus Giovani ${ }^{*}$, Hasrayati Agustina ${ }^{* *}$, Teguh M Djajakusumah ${ }^{* * *}$ \\ *Fakultas Kedokteran Universitas Padjadjaran, \\ * Departemen Patologi Anatomi, Fakultas Kedokteran \\ Universitas Padjadjaran - Rumah Sakit Umum Dr. Hasan Sadikin \\ *** Departemen Ilmu Bedah, Divisi Bedah Vaskular, Fakultas Kedokteran Universitas \\ Padjadjaran - Rumah Sakit Umum Dr. Hasan Sadikin \\ J1. Prof. Eyckman No. 38, Bandung, 40161 \\ Email : octavianusgio@gmail.com
}

\begin{abstract}
Abstrak
Tumor mediastinum merupakan salah satu kelainan di rongga mediastinum dengan berbagai spektrum klinis dan jenis histopatologi. Di Indonesia masih sedikit penelitian dan literatur mengenai tumor mediastinum. Penelitian ini bertujuan untuk mengetahui karakteristik dari tumor mediastinum di RSUP Dr. Hasan Sadikin Bandung. Penelitian ini merupakan penelitian retrospektif dengan desain studi potong lintang menggunakan data rekam medis dari tahun 2011 hingga 2016. Kriteria inklusi dari penelitian ini adalah seluruh rekam medis pasien dengan diagnosis klinis tumor mediastinum, dan kriteria eksklusinya adalah tumor mediastinum hasil metastasis organ jauh dan temuan histopatologi yang tidak sesuai. Variabel yang diteliti adalah usia, jenis kelamin, gambaran klinis, gambaran histopatologi, dan stadium pasien. Didapatkan 72 sampel yang memenuhi kriteria inklusi. Pasien tumor mediastinum kebanyakan berusia diatas 40 tahun (62,5\%), terutama pada dekade ke-6 (23,6\%), dan berjenis kelamin lakilaki $(73,6 \%)$. Pasien umumnya datang dengan keluhan sesak napas $(38,7 \%)$, diikuti oleh batuk dan gejala tipikal myasthenia gravis. Jenis tumor mediastinum yang paling sering terjadi adalah tumor sel epitel (68,4\%), dengan stadium Masaoka-Koga III (37,5\%). Simpulan, tumor mediastinum lebih banyak terjadi pada pasien di atas umur 40 tahun, berjenis kelamin laki-laki, dengan tumor sel epitel sebagai jenis histopatologi yang paling umum.
\end{abstract}

Kata kunci: karakteristik; tumor mediastinum; mediastinum 


\section{Research Article}

\section{Pendahuluan}

Mediastinum adalah suatu kompartemen di daerah toraks yang berada diantara kedua rongga pleura. ${ }^{1}$ Tumor di mediastinum dapat bersifat primer, maupun hasil metastasis dari tumor di tempat lain. Tumor mediastinum primer termasuk salah satu jenis tumor yang jarang ditemukan dibandingkan dengan tumor jenis lainnya. Laju insidensi dari timoma yang merupakan tumor mediastinum paling umum berkisar 2,2 hingga 2,6 per juta jiwa per tahunnya. ${ }^{2}$ Berdasarkan hasil penelitian dari beberapa literatur Amerika, Eropa, dan Jepang, insidensi tumor dan kista mediastinum primer dari tahun 1956 hingga 2003 adalah sebesar 718 kasus pada anak-anak, dan 3017 kasus pada orang dewasa. ${ }^{3}$ Sebuah penelitian yang diadakan di Rumah Sakit Persahabatan Jakarta Timur Indonesia menemukan 98 kasus tumor mediastinum dari bulan Januari 2002 hingga bulan Desember 2006, sedangkan penelitian lain menyatakan bahwa dari bulan Januari tahun 2007 hingga bulan Desember tahun 2008 ditemukan 27 kasus tumor mediastinum di Rumah Sakit Nasional Cipto Mangunkusumo. ${ }^{4,5}$

Tumor mediastinum memiliki berbagai varian, dan setiap varian memiliki gambaran histopatologi yang berbeda. ${ }^{6}$ Menurut WHO tahun 2015, berdasarkan gambaran histopatologinya, tumor mediastinum diklasifikasikan menjadi tumor sel epitel, tumor sel germinal, limfoma mediastinum, neoplasma sel dendritic dan histiositik, sarkoma myeloid dan leukemia myeloid akut ekstrameduler, tumor jaringan lunak, dan tumor ektopik timus. ${ }^{2}$ Dari segi usia, jenis tumor mediastinum yang paling sering terjadi pada orang dewasa adalah timoma, dan pada anak-anak adalah tumor neurogenik dan tumor sel germinal. ${ }^{1}$ Berdasarkan jenis kelamin, tumor mediastinum diketahui dapat ditemukan baik pada pria maupun wanita. Penderita tumor mediastinum primer memiliki beragam gambaran klinis, mulai dari yang bersifat asimtomatik sampai gejala yang lebih parah seperti nyeri dada, sesak napas, dan gejala paratimik seperti myasthenia gravis. ${ }^{1}$ Beberapa tumor mediastinum juga dapat dikategorikan stadiumnya, contohnya untuk tumor sel germinal menggunakan sistem TNM, dan untuk timoma menggunakan klasifikasi Masaoka-Koga. ${ }^{7}$ Saat ini, kepustakaan mengenai karakteristik dari tumor mediastinum masih sulit ditemukan, sehingga penelitian ini diharapkan dapat memperluas wawasan mengenai karakteristik tumor mediastinum dan mampu membantu klinisi dalam memperkirakan diagnosis pasien dengan tumor mediastinum serta memperkirakan gambaran histopatologi dan stadiumnya.

Tujuan dari penelitian ini adalah untuk mengetahui jumlah penderita tumor mediastinum di RSUP Dr. Hasan Sadikin Bandung periode 2011-2016 dan mengetahui karakteristik tumor mediastinum ditinjau dari umur, jenis kelamin, gambaran klinis, gambaran histopatologi dan stadium di RSUP Dr. Hasan Sadikin Bandung periode 2011-2016. 


\section{Research Article}

\section{Metode}

Penelitian ini merupakan penelitian deskriptif dan dilakukan dari bulan Mei hingga Juni 2017 menggunakan data sekunder dari Instalasi Rekam Medis RSUP Dr. Hasan Sadikin Bandung. Subjek dari penelitian ini yaitu pasien yang dirawat inap dengan diagnosis klinis tumor mediastinum di RSUP Dr. Hasan Sadikin Bandung pada periode Januari 2011 Desember 2016. Kriteria inklusi dari penelitian ini adalah seluruh data rekam medis pasien yang memiliki diagnosis klinis tumor mediastinum di RSUP Dr. Hasan Sadikin Bandung dan kriteria eksklusi adalah data rekam medis pasien dengan tumor mediastinum hasil metastasis dari organ jauh, dan data rekam medis dengan hasil pemeriksaan patologi anatomi yang tidak sesuai.

Data diambil secara retrospektif dari rekam medis pasien dengan metode total sampling. Pengambilan data dilakukan setelah mendapatan persetujuan etik nomor 330/UN6.C.10/PN/2017 yang dikeluarkan oleh Komite Etik Penelitian Kesehatan Fakultas Kedokteran Universitas Padjadjaran serta mendapat surat izin penelitian yang dikeluarkan oleh RSUP Dr. Hasan Sadikin Bandung (No. LB.02.01/X.2.2.1/9622/2017). Data yang telah diseleksi sehingga memenuhi kriteria inklusi akan dianalisis dan disajikan dalam bentuk tabel untuk menggambarkan karakteristiknya.

\section{Hasil}

Dari 82 data yang berhasil dikumpulkan, terdapat sejumlah 72 data yang memenuhi kriteria inklusi dari penelitian ini. Tabel 1 memperlihatkan karakteristik pasien dengan tumor mediastinum, ditinjau dari usia dan jenis kelamin di RSHS periode Januari 2011 hingga Desember 2016.

Tabel 1 Karakteristik Pasien Tumor Mediastinum

\begin{tabular}{lcccc}
\hline \multirow{2}{*}{ Kelompok Usia } & \multicolumn{4}{c}{$\begin{array}{c}\text { Tumor Mediastinum } \\
(\mathbf{n = 7 2})\end{array}$} \\
\cline { 2 - 5 } & Laki-laki & Perempuan & $\mathbf{N}$ & \% \\
\hline$<10$ tahun & 3 & 1 & 4 & 5,6 \\
$10-19$ tahun & 8 & 1 & 9 & 12,5 \\
20-29 tahun & 5 & 3 & 8 & 11,1 \\
30-39 tahun & 3 & 3 & 6 & 8,3 \\
40-49 tahun & 10 & 3 & 13 & 18,1 \\
$50-59$ tahun & 12 & 5 & 17 & 23,6 \\
60-69 tahun & 11 & 3 & 14 & 19,4 \\
$>70$ tahun & 1 & 0 & 1 & 1,4 \\
Total & 53 & 19 & 72 & 100 \\
\hline
\end{tabular}




\section{Research Article}

Dari Tabel 1 dapat dilihat bahwa tumor mediastinum paling sering terjadi pada kategori usia 50-59 tahun, sebanyak 23,6\%, dan jenis kelamin laki-laki, sebanyak 73,6\%. Gambaran klinis dari pasien dengan tumor mediastinum di RSUP Dr, Hasan Sadikin periode 2011-2016 dapat dilihat pada tabel 2. Gejala klinis dengan frekuensi paling tinggi adalah kesulitan bernapas yaitu sebesar 38,7\%, kemudian diikuti oleh batuk, sebesar 14,6\%.

\section{Tabel 2 Gambaran Klinis Pasien Tumor Mediastinum}

\begin{tabular}{lcc}
\hline \multicolumn{1}{c}{ Gambaran Klinis } & $\mathbf{N}$ & $\mathbf{\%}$ \\
\hline Nyeri dada & 10 & 7,3 \\
Kesulitan bernapas & 53 & 38,7 \\
Batuk & 20 & 14,6 \\
Gejala tipikal myasthenia gravis & 16 & 11,7 \\
Pembengkakan anggota tubuh & 14 & 10,2 \\
Massa di leher, thoraks, atau abdomen & 11 & 8,0 \\
Lainnya (demam, mual muntah, suara serak) & 13 & 9,5 \\
\hline
\end{tabular}

Dari seluruh data yang didapat, hanya 19 data rekam medis yang mencantumkan data tentang gambaran histopatologi dari tumor mediastinum, dan hanya 8 data rekam medis yang memiliki keterangan mengenai stadium tumor mediastinum. Tabel 3 memeperlihatkan gambaran histopatologi dari pasien tumor mediastinum di RSUP Dr. Hasan Sadikin periode 2011-2016. Dapat dilihat bahwa gambaran histopatologi dari tumor mediastinum dengan frekuensi tertinggi adalah tumor sel epitel, sebesar $68,4 \%$.

\section{Tabel 3 Gambaran Histopatologi Pasien Tumor Mediasitnum}

\begin{tabular}{|c|c|c|}
\hline Gambaran Histopatologi & $\mathbf{N}$ & $\%$ \\
\hline \multicolumn{3}{|l|}{ Tumor sel epitel } \\
\hline - Timoma tipe $\mathrm{A}$ & 1 & 5,3 \\
\hline - Timoma tipe B & 4 & 21,0 \\
\hline - Timoma tipe $\mathrm{AB}$ & 2 & 10,5 \\
\hline - Timoma NOS & 4 & 21,0 \\
\hline - Karsinoma timik & 2 & 10,5 \\
\hline \multicolumn{3}{|l|}{ Tumor sel germinal } \\
\hline - Yolk sac carcinoma & 1 & 5,3 \\
\hline - Mixed germ cell tumor & 1 & 5,3 \\
\hline \multicolumn{3}{|l|}{ Limfoma mediastinum } \\
\hline - Hodgkin limfoma & 1 & 5,3 \\
\hline \multicolumn{3}{|l|}{ Tumor mesenkimal } \\
\hline - Neurofibroma & 1 & 5,3 \\
\hline - Liposarkoma & 1 & 5,3 \\
\hline Tumor tiroid dan paratiroid ektopik & & \\
\hline - Kista duktus tiroglosus & 1 & 5,3 \\
\hline
\end{tabular}


Tabel 4 Stadium Pasien Tumor Mediastinum

\begin{tabular}{lcc}
\hline \multicolumn{1}{c}{ Stadium } & $\mathbf{N}$ & \% \\
\hline Stadium 1 & 1 & 12,5 \\
Stadium II & 2 & 25 \\
Stadium III & 3 & 37,5 \\
Stadium IVa & 0 & 0 \\
Stadium IVb & 2 & 25 \\
\hline
\end{tabular}

Tabel 4 menggambarkan stadium pasien tumor mediastinum berdasarkan klasifikasi Masaoka-Koga di RSUP Dr, Hasan Sadikin periode 2011-2016. Stadium klinis tumor mediastinum dengan frekuensi tertinggi adalah stadium III, yaitu sebanyak 37,5\%.

\section{Diskusi}

Hasil penelitian menunjukkan bahwa lebih dari setengah $(62,5 \%)$ kasus tumor mediastinum di RSUP Dr. Hasan Sadikin Bandung dari tahun 2011 hingga tahun 2016 terjadi pada kategori umur di atas 40 tahun dan lebih sering terjadi pada jenis kelamin laki-laki (73,6\%). Hal ini sesuai dengan hasil penelitian dari Amin di Jakarta (2013), dimana lebih banyak pasien penderita tumor mediastinum berusia di atas 40 tahun (56\%), dan berjenis kelamin laki-laki (67\%). ${ }^{4}$ Tumor mediastinum paling sering terjadi pada dekade ke-6 $(23,6 \%)$. Hal ini juga sesuai dengan hasil penelitian Nasit dkk (2013), dengan frekuensi terbanyak terjadi pada dekade ke-6 $(28 \%){ }^{8}$

Kebanyakan pasien penderita tumor mediastinum memiliki lebih dari satu gejala klinis. Dari hasil penelitian didapatkan bahwa kesulitan bernapas merupakan gejala klinis dengan frekuensi tertinggi $(38,7 \%)$, diikuti oleh batuk $(14,6 \%)$, dan gejala tipikal myasthenia gravis, seperti lemah badan, kelopak mata yang sulit digerakkan, dan kesulitan menelan makanan $(11,7 \%)$. Tumor mediastinum dapat menyebabkan gejala lokal maupun sistemik. Gejala lokal yang timbul dapat berupa penekanan dari struktur di rongga mediastinum akibat massa yang membesar, sehingga menyebabkan sesak napas, batuk, suara serak, nyeri dada dan kesulitan menelan, sedangkan gejala sistemik mencakup sindroma paratimik, yang menyebabkan myasthenia gravis beserta gejalanya, sindroma paraneoplastik, yang memiliki gejala seperti napsu makan yang menurun, demam dan mual muntah, dan yang lainnya. ${ }^{1,9}$ Seluruh gejala klinis tumor mediastinum tersebut dapat ditemukan pada pasien penderita tumor mediastinum dalam penelitian ini.

Dari sejumlah 72 rekam medis yang memenuhi kriteria penelitian ini, terdapat 19 rekam medis $(26,4 \%)$ yang memiliki hasil diagnosis histopatologi tumor mediastinum, dan hanya 8 data $(11,1 \%)$ yang memiliki keterangan mengenai stadium tumor mediastinum. Dari 53 data rekam medis, 14 data rekam medis $(19,4 \%)$ memiliki hasil histopatologi yang inkonklusif, dan 


\section{Research Article}

39 data $(54,2 \%)$ tidak dilakukan diagnosis histopatologi dikarenakan kematian pasien sebelum ditegakkannya diagnosis, pasien menolak prosedur diagnosis, atau sediaan yang tidak mencukupi syarat untuk pemeriksaan histopatologi. Dari 19 rekam medis yang memiliki data histopatologi didapatkan jenis tumor mediastinum dengan frekuensi tertinggi adalah tumor sel epitel $(68,4 \%)$. Hasil penelitian ini sesuai dengan penelitian yang dilakukan oleh Singh dkk (2016), dimana timoma dan karsinoma timik merupakan jenis histopatologi terbanyak yang terjadi $(31,5 \%) .{ }^{10}$ Beberapa penelitian yang menunjukkan hasil serupa antara lain penelitian oleh Amin (2013), yaitu ditemukan timoma sebanyak 33,3\% ${ }^{4}$, dan oleh Bhattarai dkk (2016), sebanyak $23,2 \%^{11}$. Beberapa hasil penelitian lain menyatakan bahwa limfoma mediastinal memiliki frekuensi yang lebih tinggi, seperti penelitian oleh Bagheri dkk (2014), sebanyak 39 kasus $^{12}$, Aroor dkk, sebanyak 34,28\% ${ }^{9}$, dan Yellapu (2016), sebanyak 30\% ${ }^{13}$. Pada penelitian, dengan menggunakan klasifikasi Masaoka-Koga, didapatkan stadium III merupakan stadium dengan frekuensi tertinggi (37,5\%). Hasil penelitian ini sesuai dengan penelitian yang dilakukan oleh Hosaka dkk (2010), dimana dari 21 kasus tumor didapatkan frekuensi stadium III sebanyak 9 kasus, dan diikuti oleh stadium IVb sebanyak 6 kasus. ${ }^{14}$

Penelitian ini tidak luput dari keterbatasan, salah satunya adalah penelitian ini menggunakan data sekunder, sehingga kelengkapan dan ketepatan data bergantung kepada dokter yang memeriksa pasien. Kelemahan lainnya adalah penelitian dan literatur lain mengenai tumor mediastinum terutama di Indonesia masih tergolong sedikit, sehingga penelitian ini lebih banyak menggunakan referensi dari literatur asing, dengan demografi yang berbeda dari tempat pelaksanaan penelitian. Penelitian ini dapat dikembangkan lebih lanjut dengan rentang waktu penelitian yang lebih lama dan variabel yang lebih lengkap.

\section{Simpulan}

Tumor mediastinum lebih banyak terjadi pada pasien di atas umur 40 tahun, terutama pada dekade ke-6, dan lebih banyak pasien laki-laki dibanding perempuan.

Gejala yang paling umum dari klinis tumor mediastinum adalah kesulitan bernapas, diikuti oleh batuk dan gejala tipikal myasthenia gravis. Frekuensi tertinggi jenis histopatologi dari tumor mediastinum dengan tumor sel epitel, dan stadium III berdasarkan klasifikasi Masaoka- Koga.

\section{Daftar Pustaka}

1. Shields TW, LoCicero J, Reed CE, Feins ,RH. General Thoracic Surgery: Philadelphia, Wolters Kluwer Health; 2011. 2055-2552.

2. Cancer IAfRo. WHO Classification of Tumours of the Lung, Pleura, Thymus and Heart: World Health Organization; 2015. 


\section{Research Article}

3. Takeda SI, Miyoshi S, Akashi A, Ohta M, Minami M, Okumura M, et al. Clinical spectrum of primary mediastinal tumors: a comparison of adult and pediatric populations at a single Japanese institution. J Surg Oncol. 2003;83(1):24-30.

4. Amin Z. Characteristics of Mediastinal Tumor Patients in Cipto Mangunkusumo National Hospital Jakarta. Indonesian Journal of Cancer. 2013;7(2):

5. Pratama S, Syahruddin E, Hudoyo A, Pulmonologi D. Karakteristik tumor mediastinum berdasarkan keadaan klinis, gambaran CT scan dan petanda tumor di rumah sakit Persahabatan. Jakarta: FKUI. 2008.

6. Rosai J. Rosai and Ackerman's Surgical Pathology: Philadelphia, Elsevier Health Sciences; 2011. 437-472.

7. Travis WD, Organization WH, Cancer IAfRo, Pathology IAo, Cancer IAftSoL. Pathology and Genetics of Tumours of the Lung, Pleura, Thymus and Heart: IARC Press; 2004. 145-247.

8. Nasit JG, Patel M, Parikh B, Shah M, Davara K. Anterior mediastinal masses: a study of 50 cases by fine needle aspiration cytology and core needle biopsy as a diagnostic procedure. SA J cancer 2013;2(1):7-8.

9. Aroor AR, Rama Prakasha S, Seshadri S, Teerthanath S, Raghuraj U. A study of clinical characteristicsof mediastinal mass. Journal of clinical and diagnostic research: JCDR. 2014;8(2):77.

10. Singh G, Amin Z, Wuryantoro W, Wulani V, Shatri H. Profile and factors associated with mortality in mediastinal mass during hospitalization at Cipto Mangunkusumo Hospital, Jakarta. Acta medica Indonesiana. 2016;45(1).

11. Bhattarai N. Cyto-histopathological study of Mediastinal lesions. J Pathol Nepal. 2016;6(11):928-31

12. Bagheri R, Afghani R, Ziaollah Haghi S, Fattahi Masoum SH, Zarehparvar Moghaddam S, Akglaghi S. Evaluation of 95 Cases with Mediastinal Tumors. J Cardio-Thor Med. 2015;3(1):249-253.

13. Yellapu GD, Numballa UR, Dharavath R, Sarella J, Mood N. Clinical profile of mediastinal masses. Lung Cancer. 2016;4:13-4.

14. Hosaka Y, Tsuchida M, Toyabe S-i, Umezu H, Eimoto T, Hayashi J-i. Masaoka Stage and Histologic Grade Predict Prognosis in Patients With Thymic Carcinoma. Ann Thor Surg. 2010;89(3):912-7. 